\title{
GREENHOUSE GAS EMISSION REDUCTION DUE TO IMPROVEMENT OF BIODEGRADABLE WASTE MANAGEMENT SYSTEM
}

\author{
R. Bendere ${ }^{*}$, I. Teibe ${ }^{2}$, D. Arina ${ }^{3}$, J. Lapsa $^{4}$ \\ 1;3 Waste Management Association of Latvia, \\ 9-2 Kursu Str., Riga, LV-1006, LATVIA \\ ${ }^{2}$ University of Latvia, \\ 10 Alberta Str., Riga, LV-1010, LATVIA \\ ${ }^{4}$ Riga Technical University, \\ 1 Kalku Str., Riga LV-1658, LATVIA \\ *e-mail: bendere@edi.lv
}

To reduce emissions of greenhouse gas (GHG) from landfills, the European Union (EU) Landfill Directive 1999/31/EC requires that there be a progressive decrease in the municipal biodegradable waste disposal. The main problem of waste management (WM) in Latvia is its heavy dependence on the waste disposal at landfills. The poorly developed system for the sorted municipal waste collection and the promotion of landfilling as a major treatment option led to the disposal of $84 \%$ of the total collected municipal waste in 2012 , with a high biodegradable fraction. In Latvia, the volume of emissions due to activities of the WM branch was 5.23\% (632.6 $\mathrm{CO}_{2}$ eq. $)$ of the total GHG emissions produced in the National economy in 2010 (12 $097 \mathrm{Gg} \mathrm{CO}_{2}$ eq., except the land use, land-use change and forestry). Having revised the current situation in the management of biodegradable waste in Latvia, the authors propose improvements in this area. In the work, analysis of environmental impact was carried out using Waste Management Planning System (WAMPS) software in the WM modelling scenarios. The software computes the emissions, energy and turnover of waste streams for the processes within the WM system such as waste collection and transportation, composting, anaerobic digestion, and the final disposal (landfilling or incineration). The results of WAMPS modelling are presented in four categories associated with the environmental impact: acidification, global warming, eutrophication and photo-oxidant formation, each characterised by a particular emission. These categories cover an integrated WM system, starting with the point when products turn to waste which is then thrown into the bin for waste at its generation source, and ending with the point where the waste transforms either into useful material (recycled material, biogas or compost) or contributes to emissions into environment after the final disposal at a landfill or an incineration plant.

Keywords: biodegradable waste, mathematical modelling, waste management 


\section{INTRODUCTION}

The aim of this work is to find the ways of how to improve the waste management (WM) system in Latvia in order to reduce disposal of biodegradable waste and generation of the greenhouse gases (GHG) at landfills.

One of the main problems to be indicated is that of strong dependence of the Latvian system for solid WM on using landfills, which, in turn, entails a number of other problems: a large amount of disposed waste; not fulfilled targets as to decreasing the disposal of biodegradable waste; as yet, a high proportion of biodegradable waste in the total disposed municipal waste; and a low proportion of the recycled household waste [1]. Also, the non-optimal organisation and performance of the mentioned system has given rise to unjustifiably large amounts of GHG emissions, and, consequently, to global environmental impact [2,3].

The data for the total yearly produced bio-waste amount in the European Union (EU) countries (as of 2010) are the following: 118-138 Mt, of which $\sim 88 \mathrm{Mt}$ originate from municipal waste, and 30-50 Mt - from industrial sources (e.g. food processing); still, in that year on the average $40 \%$ of EU produced bio-waste was landfilled, and up to $100 \%$ - in some of the member states $[4,5]$. The structure of waste material deposited at the landfills in Latvia is estimated in the research project "The Assessments of Dissolved Organic Carbon Parameters in the Landfill Waste Material" (2011). The researchers obtained the following estimates for the disposed waste content: bio-waste $-50.3 \%-51.7 \%$; plastic - 10.3\% - 11.8\%; paper/cardboard $-5.7 \%-8 \%$, glass $-10.9 \%-19 \%$; textile, rubber and leather $-3 \%-8.6 \%$; and metal $-2 \%-4.6 \%[6]$.

The European Commission (EC) investigation [4] shows that the main food waste producers are households (42\%) and the food manufacturing industry $(39 \%)$, whereas as the third bigger producer $(14 \%)$ the food service \& catering sector is named. According to the European Waste Codes (EWC) the main municipal biodegradable waste streams are classified as follows:

Kitchen and canteen waste (food waste) (20 0108 EWC code);

Garden and park waste (20 0201 EWC code);

Mixed municipal waste (20 0301 EWC code);

Waste from public market (20 0302 EWC code) including biodegradable materials' equivalents (codes $200108 \mathrm{EWC}$ and $200201 \mathrm{EWC}$ ).

\section{STATISTICAL DATA ON THE MAIN MUNICIPAL BIODEGRADABLE WASTE STREAMS}

Officially obtained statistical data on the main municipal streams of biodegradable waste mentioned before and its collection in Latvia are given in Table 1 [7]. The tabulated data show a significant discrepancy in different waste streams and treatment methods. Most probably, interpretation of statistical data is based on the reports provided by facilities and institutions while not including the waste produced by households. In the official reports the food waste (200108 EWC code) management is not stated as obligatory for the practice, and a legal possibility to interpret waste codes allows treating food waste as a mixed municipal one. Nev- 
ertheless, owing to significant improvements made in green waste (20 $0201 \mathrm{EWC}$ code) management (in particular, its total recycled amount grew to 48808 tonnes in 2013), as the main treatment method the open windrow composting is used. The majority of mixed municipal waste (20 $0301 \mathrm{EWC}$ code) is mechanically pre-treated at landfills. As could be understood from statistical reports, since 2009 in line with Regulation (EU) № 142/2011 on the animal by-products (instead of Regulation (EC) №1069/2009), the produced food waste stream is considered as municipal (Table 1).

Table 1

Main municipal bio-waste streams (tonnes) and their treatment in Latvia (2005 -2013)

\begin{tabular}{|c|c|c|c|c|c|c|c|c|c|}
\hline & \multicolumn{4}{|c|}{ Food waste (20 0108 EWC code) } & \multicolumn{5}{|c|}{$\begin{array}{l}\text { Garden and park waste (200201 EWC } \\
\text { code) }\end{array}$} \\
\hline & 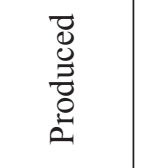 & 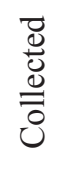 & 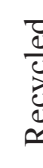 & 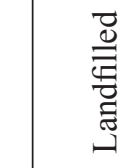 & 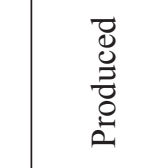 & $\begin{array}{l}\vec{d} \\
\stackrel{0}{0} \\
\stackrel{0}{0} \\
\dot{0}\end{array}$ & $\begin{array}{l}\overrightarrow{0} \\
\frac{0}{0} \\
\stackrel{0}{0} \\
\approx\end{array}$ & & 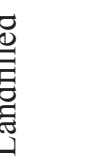 \\
\hline 2005 & 28 & - & - & 85 & - & - & - & & 2604 \\
\hline 2006 & 91 & 50 & - & 50 & - & 13010 & 4131 & & 7695 \\
\hline 2007 & 93 & 94 & - & 94 & 1926 & 14666 & 7562 & & 446 \\
\hline 2008 & 38 & 50 & - & 50 & 935 & 15526 & 7763 & & 544 \\
\hline 2009 & 33 & 11 & - & 11 & 1156 & 5127 & 3169 & & 1654 \\
\hline 2010 & 44 & - & - & - & 996 & 5348 & 4139 & & 257 \\
\hline 2011 & 32 & 888 & - & - & 4126 & 20818 & 10508 & & 799 \\
\hline 2012 & 5090 & 36 & 1 & - & 2381 & 35857 & 13180 & & 320 \\
\hline \multirow[t]{3}{*}{2013} & 54 & 33 & 1 & - & 27818 & 29874 & 48808 & & 702 \\
\hline & \multicolumn{5}{|c|}{ Mixed municipal waste (20 0301 EWC code) } & \multicolumn{4}{|c|}{$\begin{array}{l}\text { Waste from public market ( } 20 \\
0302 \text { EWC code) }\end{array}$} \\
\hline & 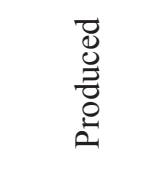 & \multicolumn{2}{|c|}{$\begin{array}{l}\overline{0} \\
\stackrel{0}{0} \\
\overline{0} \\
0\end{array}$} & $\begin{array}{l}\overrightarrow{0} \\
\frac{0}{0} \\
\vec{d} \\
\stackrel{d}{\simeq}\end{array}$ & 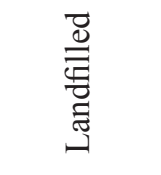 & 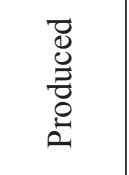 & $\begin{array}{l}\overline{0} \\
\stackrel{0}{0} \\
\stackrel{0}{0} \\
\dot{0}\end{array}$ & $\begin{array}{l}\overrightarrow{0} \\
\frac{0}{0} \\
\stackrel{0}{0} \\
\approx \\
\approx\end{array}$ & 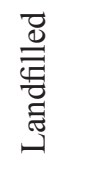 \\
\hline 2005 & 539614 & \multicolumn{2}{|c|}{ - } & 3246 & 539614 & 363 & - & - & 363 \\
\hline 2006 & 138563 & \multicolumn{2}{|c|}{884691} & 99752 & 586829 & - & 546 & - & 376 \\
\hline 2007 & 160891 & \multicolumn{2}{|c|}{745787} & 42015 & 710997 & - & 235 & - & 297 \\
\hline 2008 & 152254 & \multicolumn{2}{|c|}{670448} & 39698 & 627142 & - & 600 & - & 2 \\
\hline 2009 & 148602 & \multicolumn{2}{|c|}{533865} & 5 & 594217 & - & 647 & - & - \\
\hline 2010 & 138173 & \multicolumn{2}{|c|}{512987} & 5 & 568517 & - & 654 & - & - \\
\hline 2011 & 162675 & \multicolumn{2}{|c|}{412157} & 10828 & 509751 & - & 593 & - & - \\
\hline 2012 & 108340 & \multicolumn{2}{|c|}{495959} & 35388 & 502206 & - & - & - & - \\
\hline 2013 & 100899 & \multicolumn{2}{|c|}{510109} & 56469 & 503733 & - & - & - & - \\
\hline
\end{tabular}




\section{BIO-WASTE TREATMENT OPTIONS}

In order to elaborate the National Waste Management (WM) system for the first WM planning stage (2006-2012), the Latvian territory was divided into ten WM planning regions. In each of them one landfill for solid waste disposal was organised in compliance with the EU sanitary requirements. Mainly this was dictated by low cost of the final solid waste disposal (as compared with waste incineration) due to a low inhabitant density in the territory. Besides, landfilling allows for disposal of all materials in a solid waste stream for any WM system and technology process [8, 9].

The data presented in Table 2 show the WM performance for each municipal waste planning (MWP) region. Overall, 583069 tonnes of municipal waste were collected in 2013; exclusions from this total are: waste from septic-class tank sludge (20 0304 EWC code), waste from sewage cleaning (200306 EWC code), and bulky waste (20 $0307 \mathrm{EWC}$ code). As concerns the metal waste (20 0140 EWC code) fraction, it is corrected for the amount not related to the produced household waste.

According to the statistical data, a large discrepancy is observed between the collected and the disposed waste amounts within regions, which indicates that the industrial waste is treated as municipal; also, the recycled amount of waste varies widely for different regions. As shown in Table 2, in 2013 the collected mixed municipal waste (MW) was $219 \mathrm{~kg}_{\text {capita }}{ }^{-1}$; recycled - $30 \mathrm{~kg}$ capita $^{-1}$, and landfilled $-185 \mathrm{~kg}$ capita $^{-1}$.

Table 2

Municipal waste treatment by MWP regions in 2013

\begin{tabular}{|c|c|c|c|c|c|c|c|}
\hline MWP region & $\begin{array}{l}\text { Popula- } \\
\text { tion }\end{array}$ & $\begin{array}{l}\text { Col- } \\
\text { lected } \\
\text { mixed } \\
\text { MW }\end{array}$ & $\begin{array}{l}\mathrm{kg} \\
\text { capi- } \\
\text { ta }^{-1}\end{array}$ & $\begin{array}{l}\text { Re- } \\
\text { cycled }\end{array}$ & $\begin{array}{l}\text { kg } \\
\text { capi- } \\
\text { ta }^{-1}\end{array}$ & $\begin{array}{l}\text { Land- } \\
\text { filled }\end{array}$ & $\begin{array}{l}\text { kg } \\
\text { capi- }_{\text {ta }^{-1}}\end{array}$ \\
\hline Austrumlatgale & 94257 & 3419 & 36 & 400 & 4 & 16792 & 178 \\
\hline Dienvidlatgale & 179336 & 47789 & 266 & 470 & 3 & 52830 & 295 \\
\hline Liepāja & 147274 & 38522 & 262 & 558 & 4 & 31743 & 216 \\
\hline Maliena & 70349 & 5737 & 82 & 1529 & 22 & 7715 & 110 \\
\hline Piejūra & 138959 & 62725 & 451 & 4429 & 32 & 28821 & 207 \\
\hline Pierīga & 883228 & 249799 & 283 & 35664 & 40 & 300266 & 340 \\
\hline Ventspils & 75421 & 19393 & 257 & 733 & 10 & 7255 & 96 \\
\hline Vidusdaugava & 114723 & 14588 & 127 & 584 & 5 & 18418 & 161 \\
\hline Zemgale & 161784 & 38313 & 237 & 2405 & 15 & 27735 & 171 \\
\hline Ziemel̦vidzeme & 158494 & 29823 & 188 & 26190 & 165 & 12158 & 77 \\
\hline Total / average & 2023825 & 510106 & 219 & 72962 & 30 & 503733 & 185 \\
\hline
\end{tabular}

Klavenieks reports [10] that today less than half of disposed mixed waste could be pre-treated before landfilling (see Table 3 ). The planned waste pre-treatment 
capacity in Latvia, after establishment of a new infrastructure, will reach 701380 tonnes per year in 2016. Landfilling of mixed MW without pre-treatment or separation of the biological fraction is common practice in Latvia. Nowadays, this option is reasonably considered as a bad practice, since it is associated with environmental and safety risks caused by landfill gas collection [11] with potential GHG (in our case methane) generation, treatment of leachates as well as worthless land usage. Also, problems might arise with further application of such a material after its pretreatment at landfills (see Fig. 1).

The results of mechanical sorting of mixed waste show that the coarse fraction mostly complies with the standard for Refuse Derived Fuel (RDF). However, the content of moisture in all fractions is too high for RDF production; the separated organic fraction gives much pollution and cannot be used as compost [12]. Therefore, the separation of kitchen and garden waste at source must be a high-priority issue in municipal waste management.

The total capacity of compost plants at landfills is $29720 \mathrm{~m}^{2}$ (see Table 3). These plants are designed for composting the pre-treated fine fraction. Currently, a number of municipalities have their own green waste repositories where green waste is stored, managed and used for landscaping, but this amount is not mentioned in the public statistics reports.

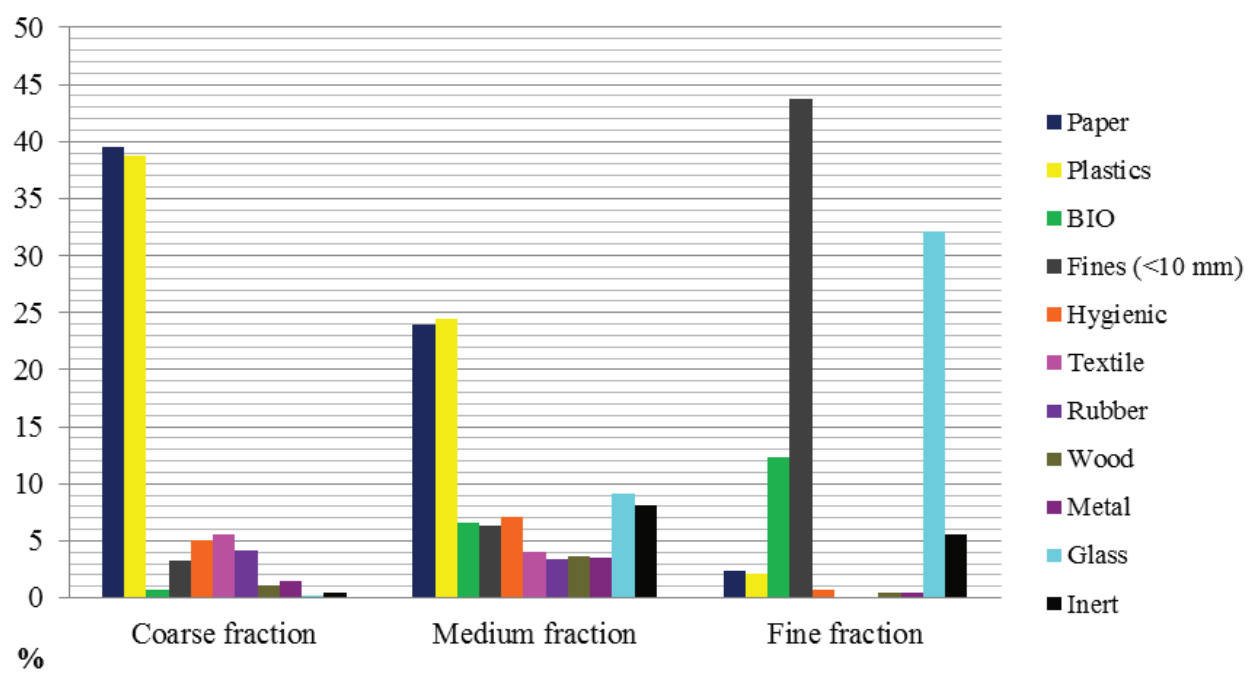

Fig. 1. The average composition of waste fractions after waste pre-treatment by a disc screener $(\%$, for dry waste)

The Latvian Biogas Association points out that 54 biogas plants are working in Latvia in 2014 with the total installed capacity of $\sim 150$ million $\mathrm{m}^{3}$, including three biogas plants at landfills (Daibe, Ķīivites and Getlinisi); one biogas plant for treatment of urban sewage sludge; two biogas plants of food industry (biogas is used directly in the combustion boiler); one wood biomass gasification facility, and 48 biogas plants in agricultural sector [13]. This allows production of $330 \mathrm{GWh}$ electricity, which suffices for heating 140000 households. 
Mixed waste pre-treatment capacity in Latvia (tonnes and $\mathbf{m}^{2}$ )

\begin{tabular}{|c|c|c|c|c|}
\hline WMPR / Operator & $\begin{array}{l}\text { Location of mechanical } \\
\text { pre-treatment } \\
\text { infrastructure }\end{array}$ & $\begin{array}{l}\text { Capacity, } \\
\text { tonnes }\end{array}$ & $\begin{array}{l}\text { Year of } \\
\text { opening? }\end{array}$ & $\begin{array}{l}\text { Area cov- } \\
\text { ered by } \\
\text { compost } \\
\text { plant, } \mathrm{m}^{2}\end{array}$ \\
\hline $\begin{array}{l}\text { Ziemelvidzeme / } \\
\text { ZAAO }\end{array}$ & Daibe, landfill & 30000 & 2011 & 5632 \\
\hline $\begin{array}{l}\text { Vidusdaugava / Vidus- } \\
\text { daugavas SPAAO }\end{array}$ & Dziḷā vāda, landfill & 80000 & 2012 & 14000 \\
\hline Liepāja / VAAO & Vibsteri, waste operator & 40000 & 2012 & \\
\hline Pierīga / Ķilupe & Ķilupe, waste operator & 14000 & 2012 & \\
\hline $\begin{array}{l}\text { Zemgale / Jelgavas } \\
\text { komunālie pakalpo- } \\
\text { jumi }\end{array}$ & Brakšksi, landfill & 30000 & 2013 & \\
\hline $\begin{array}{l}\text { Ventspils / Ventspils } \\
\text { labiekārtošanas } \\
\text { kombināts }\end{array}$ & Pentuļi, landfill & 22380 & 2013 & \\
\hline $\begin{array}{l}\text { Dienvidlatgale / } \\
\text { AADSO }\end{array}$ & Cinīši, landfill & 60000 & 2015 & 1050 \\
\hline Piejūra / AAS Piejūra & Janvāri, landfill & 40000 & 2015 & 5038 \\
\hline $\begin{array}{l}\text { Austrumlatgale / } \\
\text { ALAAS }\end{array}$ & Križevņiki, landfill & 20000 & 2015 & 2000 \\
\hline Piejūra / AAS Piejūra & Jūrmala, waste operator & 20000 & 2015 & \\
\hline Alba 5 (AP Kaudzītes) & Kaudzītes, landfill & 15000 & 2015 & 2000 \\
\hline $\begin{array}{l}\text { Pierīga / } \\
\text { Vides pakalpojumu } \\
\text { grupa/Getliṇi EKO }\end{array}$ & Getliņi, landfill & 300000 & 2016 & \\
\hline $\begin{array}{l}\text { Liepāja / } \\
\text { EKO Kurzeme/ } \\
\text { Liepājas RAS }\end{array}$ & Ķīvītes, landfill & 30000 & 2016 & \\
\hline \multicolumn{5}{|c|}{ Total mixed waste pre-treatment capacity: } \\
\hline
\end{tabular}

\section{MATERIALS AND METHODS}

In the analysis of the environmental impact due to activities of WM branch the Waste Management Planning System (WAMPS) software was used for modelling the relevant scenarios. The new version of WAMPS (see Fig. 2) allows the user to create more scenarios for WM development, since it has been complemented with a mechanical pre-treatment process in which new fractions (metal, fine fraction and 
RDF) are produced. The new waste material technology - incineration in the cement kiln - is also one of the solutions allowing the use of waste as burning material that would partly replace fossil resources.

The WAMPS software calculates emissions, energy and turnover of waste streams for processes within the WM system, e.g., waste collection and transportation, composting, anaerobic digestion, and final disposal - landfilling or incineration [14].

The software is based on the Life Cycle Assessment (LCA) approach, and the results of modelling are presented in four environmental impact categories: acidification, global warming, eutrophication and photo-oxidant formation, each characterised by a particular emission. This paper focuses only on the global warming category.

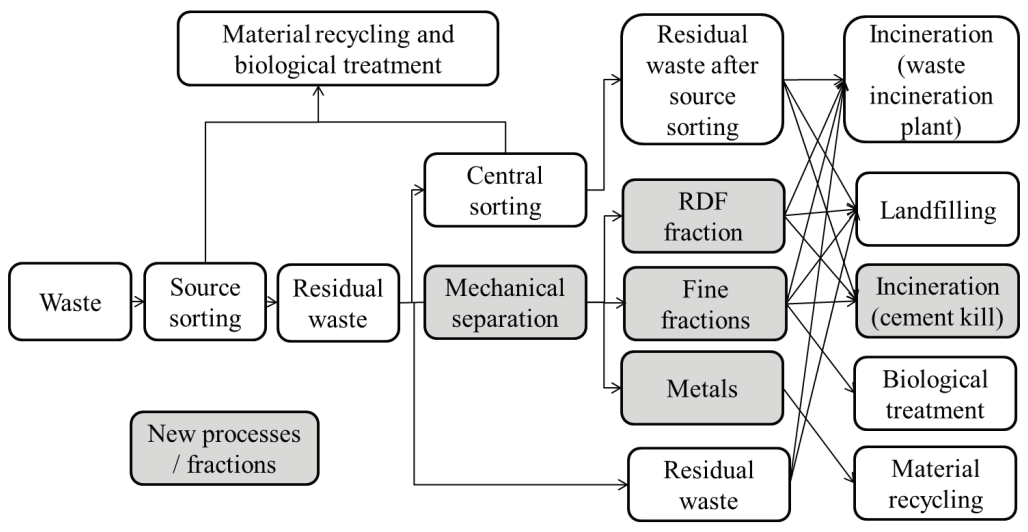

Fig. 2. Overview of WAMPS modelling possibilities

The WAMPS covers an integrated WM system - starting with the activities where products become waste and put into the waste bin at its generation source - to the last point where the waste transforms either to useful material (recycled material, biogas or compost) or contributes to emissions into the environment after its final disposal at a landfill or an incineration plant. The computation can give also negative net emissions: for example, a WM system with incineration could give lower emissions than the corresponding energy production in the background system (based on fossil fuels). The net emissions in each of the WM scenarios are calculated by the following equation [15]:

$$
E_{\text {net }}=E_{\text {waste }}-E_{\text {background }}
$$

where $E_{n e t}-$ the net emissions (tonnes year-1);

$E_{\text {waste }}$ - emissions caused by the WM processes during which a definite amount of products (tonnes/year) or energy are obtained;

$E_{\text {background }}$ - emissions from the same volume of alternative virgin production in the background system (tonnes year ${ }^{-1}$ ).

In the development of WAMPS software a number of limitations were revealed and eliminated. 


\subsection{Waste amount and composition}

For the modelling purpose, it is assumed that the total collected amount of municipal waste corresponds to the produced amount listed in the publicly available No.

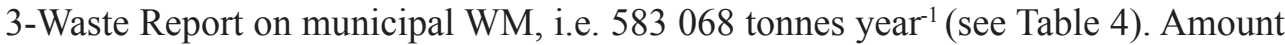
of such waste from the institutions and small enterprises (185 624 tonnes year ${ }^{-1}$ ) is shown in the Produced Waste section of statistical data [7]. According to the Eurostat report [16], 64\% of the total Latvian population are living in the apartment buildings, which implies the following shares for the rest of total collected municipal waste: $64 \%$ (or 254364 tonnes year $^{-1}$ ) from multi-storey buildings and 36\% (or 143080 tonnes year-1) from private houses.

Table 4

Municipal waste composition (tonnes year ${ }^{-1}$ and $\%$ by weight)

\begin{tabular}{llll}
\hline & $\begin{array}{l}\text { Institutions and } \\
\text { small enterprises }\end{array}$ & $\begin{array}{l}\text { Multi-storey } \\
\text { buildings }\end{array}$ & $\begin{array}{l}\text { Private } \\
\text { houses }\end{array}$ \\
\hline Waste amount, tonnes & 185624 & 254364 & 143080 \\
\hline Waste fraction, \% by weight & & & $11 \%$ \\
\hline Paper and cardboard & $32 \%$ & $10 \%$ & $3 \%$ \\
\hline Newspaper, magazines, etc. & $7 \%$ & $3 \%$ & $21 \%$ \\
\hline Plastic & $27 \%$ & $28 \%$ & $2 \%$ \\
\hline $\begin{array}{l}\text { Metal packaging (aluminium and } \\
\text { steel) }\end{array}$ & $1 \%$ & $2 \%$ & $8 \%$ \\
\hline Glass & $4 \%$ & $8 \%$ & - \\
\hline Rubber, incl. tyres & - & - & - \\
\hline Clothes, shoes, textiles and leather & - & - & $1 \%$ \\
\hline Wood & - & - & $19 \%$ \\
\hline Biodegradable material (mixed & - & $13 \%$ & $20 \%$ \\
\hline Organic degradable kitchen waste & $10 \%$ & $29 \%$ & - \\
\hline Garden Waste & $14 \%$ & - & $3 \%$ \\
\hline Hazardous waste & $1 \%$ & $2 \%$ & $4 \%$ \\
\hline $\begin{array}{l}\text { Electric and electronic wastes } \\
\text { (WEEE) }\end{array}$ & - & - & $5 \%$ \\
\hline Inert wastes & $3 \%$ & $5 \%$ & - \\
\hline Non-hazardous batteries & - & - & $100 \%$ \\
\hline Steel and metal scrap (mixed) & - & - & \\
\hline Others & $1 \%$ & $100 \%$ & $2 \%$ \\
\hline Total & $100 \%$ & & \\
\hline
\end{tabular}

It is assumed that the municipal waste composition in the country corresponds to that estimated for the Ogre municipality (39 233 inhabitants). In Table 4, the composition of the sorted and measured waste amount (28 tonnes) is given for the summer season [17].

According to the survey for the Marupe municipality - a Riga's suburb with 10000 inhabitants of whom 5000 live in private houses - in 2014 two thirds of 171 respondents confirm that they have already organised the green waste backyard com- 
posting. This is taken into account in view of the task to realise the target of Landfill Directive and meet its requirements on biodegradable waste. According to the worked out scenarios, all private householders are to reduce the green waste amount at source gradually: 50\% of weight in Scenario 1 and up to 100\% - in Scenarios 2 and 3 by home composting.

Having estimated the statistical data and waste composition, the institutions are able to fulfil green waste treatment targets already now by $100 \%$ separation of the produced green waste. The treatment can be done using open windrow composting.

As mentioned above, the third largest producer of food waste is the food service and catering sector. This sector is accounted for in Scenario 2, while householders living in multi-storey buildings are added to Scenario 3.

Currently, the Waste Framework Directive objectives are rather ambitious for Latvia, so now a less ambitious goal is chosen, i.e. $25 \%$ source sorting of the waste materials: paper / cardboard, glass, plastic and metal in Scenarios 1 - 3 (see Table 5 and Fig. 3).

Table 5

Waste sorting at source in the studied waste management scenarios $(\%$, tonnes)

\begin{tabular}{|c|c|c|c|c|c|c|c|c|}
\hline \multirow[b]{2}{*}{ Scenario } & \multirow[b]{2}{*}{$\begin{array}{l}\text { Paper } \\
\text { / card } \\
\text {-board }\end{array}$} & \multirow[b]{2}{*}{ Glass } & \multirow[b]{2}{*}{ Plastic } & \multirow[b]{2}{*}{ Metal } & \multicolumn{2}{|c|}{ Food waste } & \multicolumn{2}{|c|}{ Green waste } \\
\hline & & & & & $\begin{array}{l}\text { Institu- } \\
\text { tions }\end{array}$ & $\begin{array}{l}\text { Multi- } \\
\text { storey } \\
\text { buil- } \\
\text { dings }\end{array}$ & $\begin{array}{l}\text { Institu- } \\
\text { tions }\end{array}$ & $\begin{array}{l}\text { Pri- } \\
\text { vate } \\
\text { houses }\end{array}$ \\
\hline Base & $18 \%$ & $13 \%$ & $7 \%$ & $15 \%$ & \multicolumn{2}{|c|}{$<1 \%$} & $100 \%$ & - \\
\hline Scenario 1 & $25 \%$ & $25 \%$ & $25 \%$ & $25 \%$ & - & - & $100 \%$ & $50 \%$ \\
\hline Scenario 2 & $25 \%$ & $25 \%$ & $25 \%$ & $25 \%$ & $100 \%$ & - & $100 \%$ & $100 \%$ \\
\hline Scenario 3 & $25 \%$ & $25 \%$ & $25 \%$ & $25 \%$ & $100 \%$ & $100 \%$ & $100 \%$ & $100 \%$ \\
\hline
\end{tabular}

After the source sorting of waste material (paper, plastics, glass, metallic packages and bio-waste), the rest of waste (mixed) is transported to a landfill equipped with a mechanical sorting line for pre-treatment. According to the results of investigation [12], the following four fractions are separated from the total mixed household waste mass:

$\sim 35 \%$ - fine fraction mainly composed of organic waste;

$\sim 40 \%$ - medium fraction of diversified waste;

$\sim 22 \%$ - coarse fraction (RDF) containing waste of high calorific

value (plastics, paper, textile, rubber);

$\sim 3 \%$ - iron-containing fraction.

This percentage was used in mechanical sorting calculations in the considered WM scenarios. 


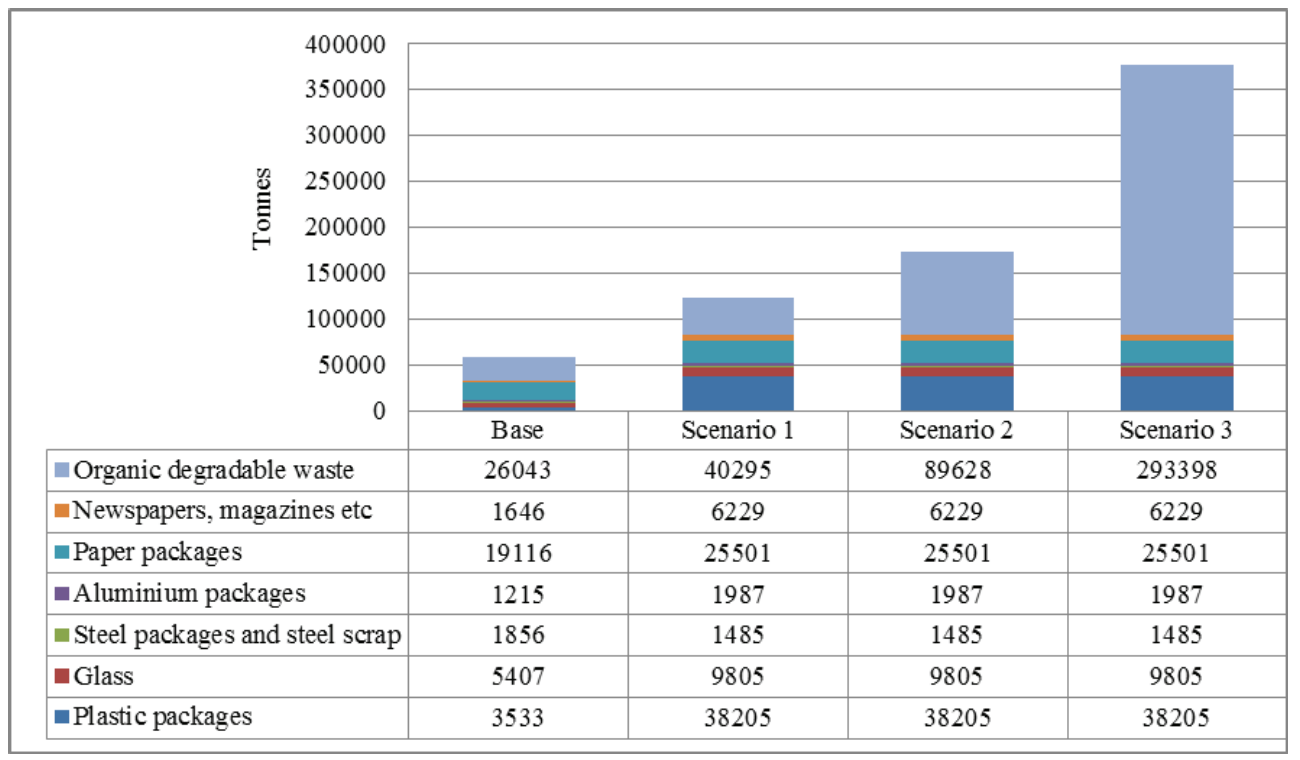

Fig.3. Projection of waste recycling (tonnes) in the studied waste management scenarios

\subsection{Waste management scenarios and technologies}

For the Latvian WM system a base scenario and three alternative scenarios have been developed (Table 6). The scenarios are hypothetical, and characterise possible trends in the development of food waste and green waste management in Latvia towards reducing GHG emissions. The base scenario relates to the situation existing in the country.

The assumptions made in the mathematical design of the models are (see Table 6 and Fig. 4):

1. the biodegradable waste composting produces compost that is $60 \%$ of the total mass and is used as fertiliser for landscaping, agricultural or local consumption at home;

2. in all scenarios the energy produced from landfill gas and waste incineration replaces fossil fuel in a background system (i.e. natural gas);

3 . in all scenarios the landfill gas is recovered and combusted with $35 \%$ efficiency $[11,12,16,18]$, i.e. providing $50 \%$ of district heating and $40 \%$ of electricity;

4. the energy recovery from incineration process is $20 \%$ of electricity and $80 \%$ of district heating; incineration process complies with EU requirements. 
Main characteristics of studied waste management scenarios

\begin{tabular}{|c|c|c|c|c|c|c|c|c|c|}
\hline \multirow[b]{2}{*}{ :을 } & \multirow[b]{2}{*}{ 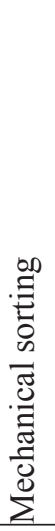 } & \multicolumn{3}{|c|}{$\begin{array}{l}\text { Biodegradable organic } \\
\text { waste } \\
\text { (after source sorting) }\end{array}$} & \multirow[b]{2}{*}{$\begin{array}{l}\text { Fine frac- } \\
\text { tion (after } \\
\text { mechani- } \\
\text { cal sort- } \\
\text { ing). } \\
\text { Compos- } \\
\text { ted and } \\
\text { used as } \\
\text { covering } \\
\text { material } \\
\text { for dis- } \\
\text { posal site }\end{array}$} & \multicolumn{3}{|c|}{$\begin{array}{l}\text { RDF fraction } \\
\text { (after mechanical } \\
\text { sorting) }\end{array}$} & \multirow[b]{2}{*}{ 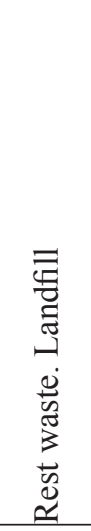 } \\
\hline & & 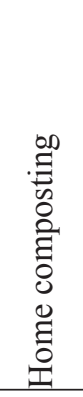 & 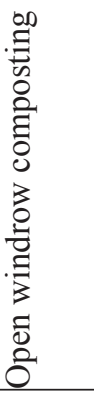 & 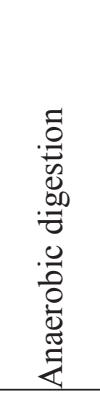 & & 丰 & 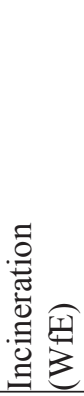 & 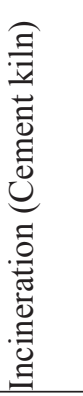 & \\
\hline Base & + & - & $100 \%$ & - & $100 \%$ & $100 \%$ & - & - & $100 \%$ \\
\hline \multirow{2}{*}{ Scenario 1} & \multirow{2}{*}{+} & \multicolumn{2}{|c|}{$100 \%$} & - & \multirow{2}{*}{$100 \%$} & \multirow{2}{*}{$80 \%$} & \multirow{2}{*}{$10 \%$} & \multirow{2}{*}{$10 \%$} & \multirow{2}{*}{$100 \%$} \\
\hline & & $35 \%$ & $65 \%$ & - & & & & & \\
\hline \multirow{2}{*}{ Scenario 2} & \multirow[b]{2}{*}{+} & \multicolumn{2}{|c|}{$75 \%$} & $25 \%$ & \multirow{2}{*}{$100 \%$} & \multirow{2}{*}{$80 \%$} & \multirow{2}{*}{$10 \%$} & \multirow{2}{*}{$10 \%$} & \multirow{2}{*}{$100 \%$} \\
\hline & & $52 \%$ & $48 \%$ & $100 \%$ & & & & & \\
\hline \multirow{2}{*}{ Scenario 3} & \multirow{2}{*}{+} & \multicolumn{2}{|c|}{$30 \%$} & $70 \%$ & \multirow{2}{*}{$100 \%$} & \multirow{2}{*}{$80 \%$} & \multirow{2}{*}{$10 \%$} & \multirow{2}{*}{$10 \%$} & \multirow{2}{*}{$100 \%$} \\
\hline & & $53 \%$ & $47 \%$ & $100 \%$ & & & & & \\
\hline
\end{tabular}

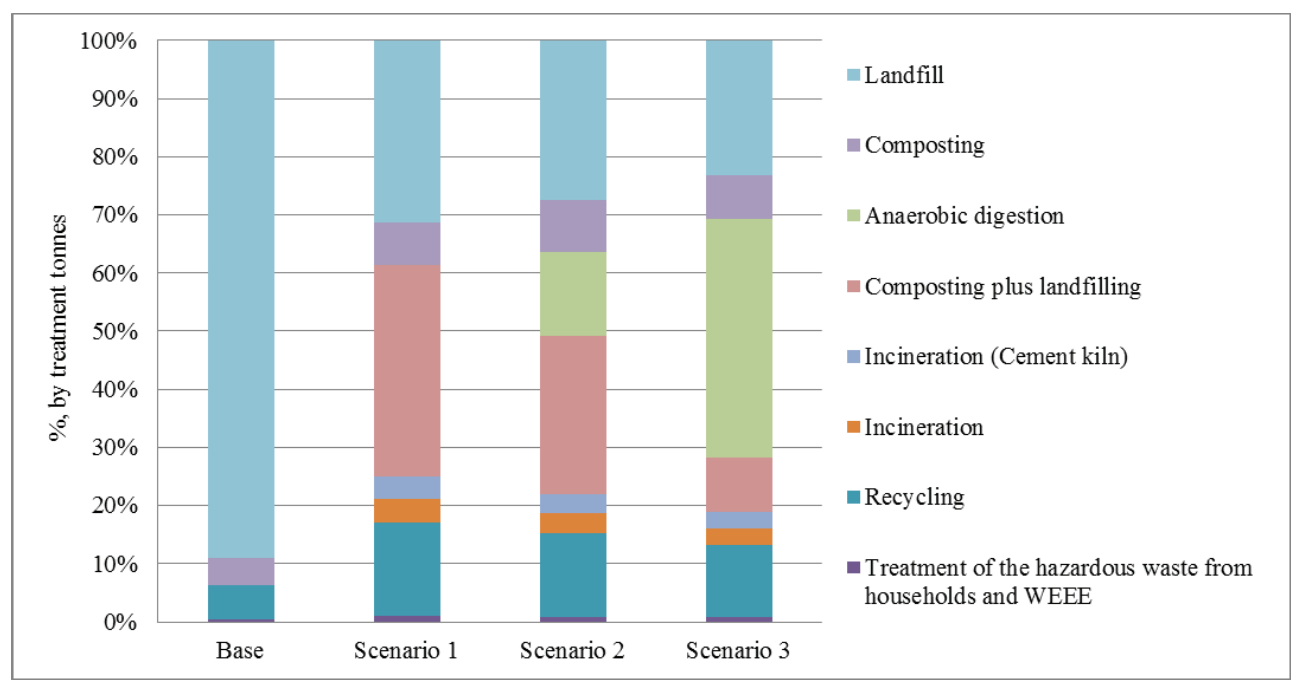

Fig.4. Projection of treatment for studied waste management scenarios ( $\%$ by weight)

\section{RESULTS}

The results of LCA modelling of the scenarios under consideration show that the abandonment of biodegradable waste disposal at landfills leads to significant GNG reduction. The global warming as the focus of our research is illustrated by Fig. 5 and Table 7 for all the scenarios. 


\section{Global warming}

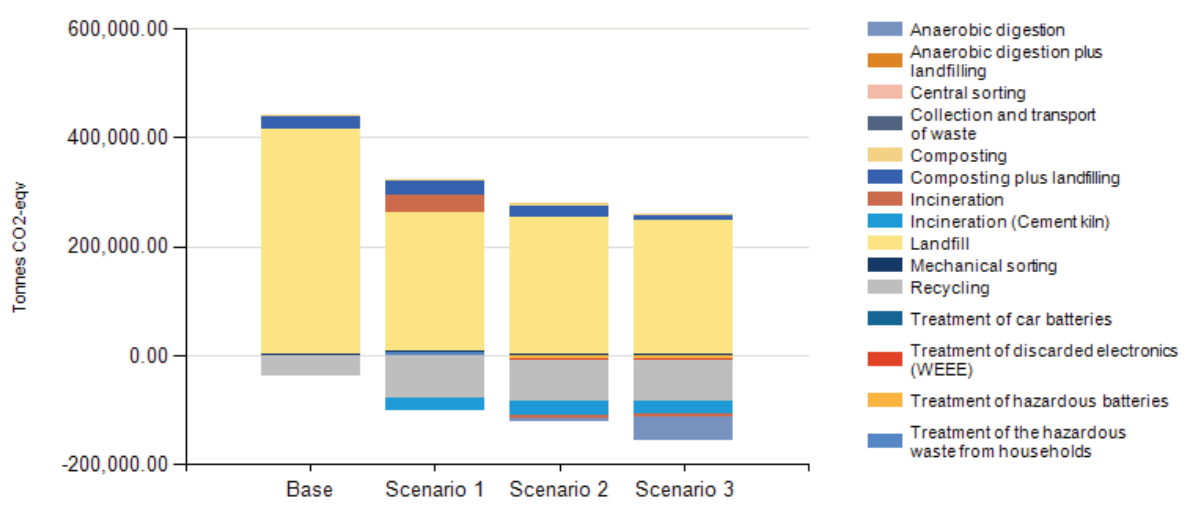

Fig.5: Overview of global warming in the studied waste management scenarios (tonnes $\mathrm{CO}_{2}$ eqv)

The diagrams in Fig. 5 show the net emissions from each WM technology minus the saved emissions in the background system. The negative results imply the avoided impacts and fossil fuel savings.

According to the modelled scenarios, the total GHG emissions can be reduced from 404700 tonnes $\mathrm{CO}_{2}$ eqv in Base scenario to 222127 tonnes in Scenario 1, 158 526 tonnes in Scenario 2, and to 92333 tonnes in Scenario 3.

Table 7

Global warming emissions for each waste treatment technology (tonnes $\mathrm{CO}^{2}$ eqv.)

\begin{tabular}{|l|c|c|c|c|c|c|}
\hline & $\begin{array}{l}\text { Anaero- } \\
\text { bic diges- } \\
\text { tion }\end{array}$ & $\begin{array}{l}\text { Com- } \\
\text { posting }\end{array}$ & $\begin{array}{l}\text { Compos- } \\
\text { ting plus } \\
\text { landfilling }\end{array}$ & $\begin{array}{l}\text { Incinera- } \\
\text { tion (WfE) }\end{array}$ & $\begin{array}{l}\text { Incinera- } \\
\text { tion (Ce- } \\
\text { ment kiln) }\end{array}$ & Landfill \\
\hline Base & - & 2981 & 23159 & - & - & 415037 \\
\hline Scenario 1 & - & 4526 & 24569 & -32346 & -24497 & 255230 \\
\hline Scenario 2 & -6836 & 5891 & 20746 & -7152 & -24104 & 252958 \\
\hline Scenario 3 & -43162 & 5422 & 8301 & -6284 & -22853 & 246070 \\
\hline & $\begin{array}{l}\text { Mechani- } \\
\text { cal sort- } \\
\text { ing }\end{array}$ & $\begin{array}{l}\text { Recy- } \\
\text { cling }\end{array}$ & $\begin{array}{l}\text { of discarded } \\
\text { electronics } \\
\text { (WEEE) }\end{array}$ & $\begin{array}{l}\text { Treat- } \\
\text { hent of } \\
\text { batteries }\end{array}$ & $\begin{array}{l}\text { Treatment of the } \\
\text { hazardous waste from } \\
\text { households }\end{array}$ \\
\hline Base & 1619 & -36533 & -1548 & -109 & \multicolumn{2}{|c|}{95} \\
\hline Scenario 1 & 1485 & -76897 & -1998 & -4842 & \multicolumn{2}{|c|}{-1662} \\
\hline Scenario 2 & 1372 & -76897 & -1998 & -4842 & \multicolumn{2}{|c|}{-1662} \\
\hline Scenario 3 & 1016 & -76897 & -1998 & -4842 & \multicolumn{2}{|c|}{662} \\
\hline
\end{tabular}




\section{CONCLUSIONS}

In the work it is convincingly shown that landfilling (Base Scenario) as the final disposal waste treatment method is the major source of GHG emissions (mainly $\mathrm{CH}_{4}$ ), since the effectiveness of recovering the landfill gas is low.

A significant net positive environmental impact has been made by the use of material recycling and incineration (especially in a cement kiln). In these processes the heat and electricity are produced, which allows for saving virgin materials and fossil fuels, also reducing the disposed waste amount at landfills.

The sorting of food waste at source which reduces its content in the fine fraction for composting and landfilling widens possibilities to use such waste as valuable material and to reduce significantly disposed waste at landfills. Also, the food waste separated at source presents a useful input material for the energy recovery and production from biogas which would partly replace the energy derived from fossil fuels (coal, oil, gas).

Composting may result in $\mathrm{CO}_{2}$ emission arising in the decomposition process of organic matter, also after the compost is added to the soil and from turning mechanically a compost pile. At the same time, if the composting process is managed properly, no $\mathrm{CH}_{4}$ emission arises from anaerobic decomposition.

The current statistics shows insufficiency of reliable data on the produced food waste amount and its content, which reduces the effectiveness of waste treatment planning. Therefore, the results of our pilot research are of vital importance.

In the future, for WM system an essential requirement will be to prepare food waste for anaerobic digestion in the planned amount and with invariable quality; therefore, thermal stabilisation of food waste is desirable.

In order to make feasible the anaerobic digestion of food waste - since composting only food waste without any other organic material will be extremely difficult - it is necessary to create new or integrate the existing alternative systems for energy consumption. It is rational to combine the production facilities with agriculture, transport or other ones.

The green waste composting is a rational option when the produced compost is valuable and is needed as soil improver. Therefore, government has to create legislative and economic instruments for adequate stimulation of the compost market and of using the produced material for landscaping, road construction, etc.

In the case of Latvia, home composting in private houses is very feasible, making it possible to significantly reduce the amount of treated municipal waste. Therefore, the local municipal support and the campaigns of home composting awareness are extremely important. 


\section{REFERENCES}

1. BiPRO. (2012). Screening of Waste Management Performance of EU Member States. Beratungsgesellschaft für integrierte Problemlösungen. Brisele: European Commission. Retrieved May 19, 2014 from http://ec.europa.eu/environment/waste/studies/pdf/ Screening_report.pdf

2. Eurostat. (2012). Greenhouse gas emissions by sector. Luxemburg: Eurostat. Retrieved January 21, 2013 from http://epp.eurostat.ec.europa.eu

3. UNFCCC. (2012). National Inventory Submissions. United Nations Framework Contention on Climate Change. Retrieved January 10, 2013 from http://unfecc.int/national_reports/annex_i_ghg_inventories/national_inventories_submissions/items/6598.php

4. BIO Intelligence, S. (2011). Preparatory Study on Food Waste Across EU 27. European Communities. doi:DOI : 10.2779/85947

5. JRC. (2014). End-of-waste criteria for biodegradable waste subjected to biological treatment (compost \& digestate): Technical proposals. Joint Research Centre, Luxembourg. doi:ISSN 1831-9424

6. Virsma Ltd (2011). Degradējamā organiskā oglekḷa daḷas noteikšana apglabātos atkritumos (Report of Latvia's national greenhouse gas emission inventory) Riga

7. LEGMC. (2014). Valsts statistisko pārskats "3-Atkritumi" (State Statistical Review "3-Waste"). Latvian Environment, Geology and Meteorology Centre, State Ltd, Riga. Available at: http://parissrv.lvgmc.lv/\#viewType=home_view (Accessed 29.08.2014)

8. Mc Dougall, F., White, P., Franke, M., \& Hindle, P. (2003). Integrated Solid Waste Management: a Life Cycle Inventory. In F. W. Mc Dougall, Integrated Solid Waste Management: a Life Cycle Inventory (p. 513). Oxford, UK: Blackwell Science.

9. Tchobanoglous, G., Theisen, H., \& S, V. (1993). Integrated Solid Waste Management. Engineering Principles and Management Issues. (p.978) Singapore: McGraw-Hill Book Co. doi:ISBN 0-07-112865-4

10. Kḷavenieks, K. (2014. gada 17. 10). Eiropas Savienības fondu 2014. - 2020. gada finanšu plānošanas perioda potenciāli atbalstāmo vides aizsardzības aktivitāšu ekonomisko ieguvumu novērtējums. (Potentially supported environmental protection activities and its economic assessment for the next European Union Funds financial programming period 2014 - 2020,) Riga: Oral presentation. Geo Consultants, SIA

11. Arina, D., Bendere, R., \& Teibe, I. (2012). Pre-treatment Processes of Waste Reducing the Disposed Amount of Organic Waste and Greenhouse Gas Emission. Congress proceedings (p. 517 pdf). Florence: The ISWA World Solid Waste Congress 2012.

12. Kalnacs, J., Arina, D. and Murashov, V. (2013), "Content and Properties of Mechanically Sorted Municipal Wastes and Their Suitability for Production of Alternative Fuel," Renewable Energy \& Power Quality Journal, pp. 1-4. doi:ISSN:2172-038X

13. Dubrovskis, V., Niklass, M., Emsis, I., \& Kārklinšs A, (2013). Biogāzes ražošana un efektīva izmantošana (Production of biogas and effective consumption), Latvijas Biogāzes asociācija, Rīga. Retrieved November 10, 2014 from http://latvijasbiogaze.lv/ files/Buklet_LQ.pdf

14. IVL. (2013). Joint Baltic Sea Region Strategy for Municipal Waste Management. IVL Swedish Environmental Research Institute. Retrieved from www.recobaltic21.net

15. Moora, H. (2009). Life Cycle Assesment as a Decision Support Tool for System Optimisation - the Case of Waste Management in Estonia, Tallinn: Tallinn University of Technology p. 174. doi:ISSN 1406-4766 


\title{
BIOLOĢISKI NOĀRDĀMO ATKRITUMU APSAIMNIEKOŠANAS UZLABOŠANA SILTUMNĪCEFEKTA GĀZU SAMAZINĀŠANAI
}

\author{
R. Bendere, I. Teibe, D. Arina, J. Lapsa
}

K ops avi $1 \mathrm{kums}$

Rakstā veikts pašvaldības bioloǵiski noārdāmo atkritumu apsaimniekošanas statistikas datu novērtējums atbilstoši likumdošanas prasībām. Izmantojot matemātisko modelēšanas programmu WAMPS, analizēti trīs dažādi bioloǵisko noārdāmo atkritumu apsaimniekošanas scenāriji, kuriem veikts vides ietekmes novērtējums, kas izteikts klimata pārmainu potenciālā - tonnas $\mathrm{CO}_{2} \mathrm{ekv}$

Darbā secināts, ka lielākais siltumnīcefektu (SEG) avots atkritumu apsaimniekošanas ir atkritumu poligoni (Bāzes scenārijs), ko galvenokārt ietekmē $\mathrm{CH}_{4}$ rašanās, organiskajiem atkritumiem sadaloties anaerobos apstākḷlos. Būtisku pozitīvo efektu SEG emisiju samazināšanā dod atkritumu pārstrāde otrreizējās izejvielās un sadedzināšana cementa ražotnē, kas ḷauj samazināt dabīgo izejmateriālu un fosilo energijas resursu patēriņu.

Attīstot pārtikas atkritumu pārstrādi biogāzē, lietderīgi veidot alternatīvās vai izmantot esošās sistēmas, kas nodrošina iegūtās enerğijas un digestāta patēriṇu, t.i lauksaimniecība, transports vai komunālie pakalpojumi.

Lai no zalıjiem dārza atkritumiem iegūtu augstvērtīgu kompostu, valstī jārada tam nepieciešami likumdošanas un ekonomiskie instrumenti, kas veicina komposta tirgus attīstību.

22.11.2014 